\title{
Phenotypic variability in a cohort of 40 Italian subjects carrying mutations in the gene EDA
}

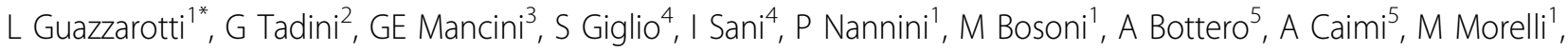 \\ GV Zuccotti ${ }^{1}$
}

From 5th International Conference on Ectodermal Dysplasia (ED2012)

Erlangen, Germany. 1-3 June 2012

Ectodermal dysplasias (ED) are a group of clinically and genetically heterogeneous conditions commonly characterized by abnormal development of at least two structures derived from the embryonal ectoderm (hair, teeth, nails, and sweat glands). X-linked hypohidrotic ED, which is caused by mutations in the gene EDA (MIM 305100), is the most frequent form. In this study, we investigated the phenotype of 40 male patients, aged 2 to 20 years, who all showed developmental defects of ectodermal derivatives and a mutation in $E D A$. Specialist assessments of the involved organ systems were performed. 95\% of these patients presented with impairment of sweating, which was only moderate in $35 \%$, while two subjects did not show any alteration of sweat gland function. Severe oligodontia was found in $80 \%$ of the subjects, $10 \%$ had hypodontia. $90 \%$ of the patients showed abnormal crown morphology of the teeth. Severe involvement of the scalp hair was observed in $22 \%$ of the patients, moderate involvement in $72 \%$, and no relevant alterations of hair morphology, quantity or growth in 2 patients. Onychodystrophy was seen in 67\% of our patients. Concerning minor alterations of ectodermal tissues, we found dry eye signs in $92 \%$ of the subjects investigated, recurrent respiratory infections in $82 \%$, hearing loss in $10 \%$, atopic dermatitis in $35 \%$, and a neuropsychological disorder in $10 \%$. Our study shows that an $E D A$ mutation can be present in males also in the context of only one of the major clinical signs of Xlinked ED, but associated with minor alterations. Therefore we suggest that $E D A$ gene analysis should be considered also for males with a mild ED phenotype.

'Department of Pediatrics, University of Milan, Italy

Full list of author information is available at the end of the article
Author details

'Department of Pediatrics, University of Milan, Italy. ${ }^{2}$ RRCCS Ca' Granda Policlinico Hospital, Milan, Italy. ${ }^{3}$ RCCS Galeazzi, Milan, Italy. ${ }^{4}$ University of Florence, Italy. ${ }^{5}$ University of Milan, Italy.

Published: 25 May 2012

\section{doi:10.1186/1746-160X-8-S1-P2}

Cite this article as: Guazzarotti et al:: Phenotypic variability in a cohort of 40 Italian subjects carrying mutations in the gene EDA. Head \& Face Medicine 2012 8(Suppl 1):P2.
Submit your next manuscript to BioMed Central and take full advantage of:

- Convenient online submission

- Thorough peer review

- No space constraints or color figure charges

- Immediate publication on acceptance

- Inclusion in PubMed, CAS, Scopus and Google Scholar

- Research which is freely available for redistribution
() Biomed Central 